\title{
Virtual learning of the tribal students in Bangladesh: Constrictions and propositions
}

\author{
Quazi Farzana Yesmin', Mohammad Ehsanul Islam Khan ${ }^{2}$ \\ ${ }^{1}$ Department of English, City University, Dhaka, Bangladesh \\ ${ }^{2}$ Department of English, Manarat International University, Dhaka, Bangladesh
}

\begin{abstract}
Article Info
Article history:

Received Dec 18, 2020

Revised Jun 13, 2021

Accepted Jul 15, 2021

Keywords:

Internet facility

Learner sensitivities

Learning constrictions

Tribal students

Virtual education

ABSTRACT

This paper depicts the current panorama of virtual learning of the tribal students in Bangladesh with the constrictions and possible solutions. The study aimed to deal with the major issues about tribal students' online education by bringing out the key restraints of their distance learning and the possible solutions. The researchers followed a mixed method using a 5-point Likert Scale to point out the learner sensitivities, an online Focus Group Discussion (FGD) to know specific information from all the tribes who participated in the study. Additionally, four different questions were also set for multiple response analyses. The results suggested that the tribal students have not agreeably received adequate facilities such as technological support, university funding, departmental encouragements, or monetary benefits from the quota system in the current pandemic (COVID-19) time to attend virtual learning sessions though they expect arrangements and future steps for academic learning. All institutions also could not provide them adequate opportunities to attend online classes. In conclusion, the study proposed some imperative measures for example, inclusion of flipped classroom, introducing blended learning henceforth, revising quota facilities, adequate electricity support and internet connection, to help the tribal students as they should not get deprived.
\end{abstract}

This is an open access article under the CC BY-SA license.

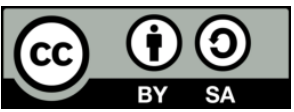

Corresponding Author:

Mohammad Ehsanul Islam Khan

Department of English

Manarat International University (MIU)

Plot \# CEN-16, Road-106, Gulshan, Dhaka-1212, Bangladesh

Email: asad.helloteen@gmail.com

\section{INTRODUCTION}

An estimated 370-500 million indigenous people globally spread across 90 countries representing five thousand different cultures with unique practices [1]. More than 54 indigenous groups of "around four million people" [2] live in Bangladesh using 35 languages, together with the mainstream of the Bengali residents [3]. Most of the tribal groups are found in the hilly areas of the Chattogram division and a few groups in the northern part of Bangladesh along with others in the Mymensingh, Tangail, and Netrokona. In modern society, education is considered to be the main force for social mobility [4]. But continuing education is not easy as pie for the tribal students as most of the students have their native tongue other than in Bangla. Khan [2] mentioned that the inability of indigenous children's understanding of the textbook and the Bengali medium instruction in the classroom is one of the causes for their early dropouts from education. They also frequently face higher school drop-out risks [5]. However, the handful of students who come to the tertiary education also faces critical issues to continue education. The language of instruction, their remote living areas, their studying institutions, logistic and social supports along with their special privileges are still to be 
developed to a satisfactory level. So, in connection with the current pandemic time, the tribal students are facing multifaceted troubles to continue their education. However, virtual education is becoming a mainstay of learning for all; especially during the coronavirus disease in 2020, the entire world has experienced the urgency of online distance education. In these recent days, virtual learning or online distance education gets much attention due to the exigency of learning from home.

Despite being appreciated globally, in Bangladesh, virtual learning or online education is at its early stage. Educational institutions including all higher educational institutions in the country are experiencing the primary phase of adopting such modern technologies. These emerging approaches hold promise as a means of democratizing education [6]. Therefore, providing all technical supports to the students for virtual learning henceforth has been one of the utmost concerns in Bangladesh. Providing education to all as a basic need often becomes more challenging, especially, in the case of virtual education. It makes unequal access to internet technology among the world's most susceptible populations who lack the "digital capital" to access online educational resources [7]. Consequently, education right for all including the tribal students has become a burning question for the 'new normal' world.

Bangladesh is a land of more than 45 tribal groups who live in different regions of the country [8]. International Labour Organization [9] depicted that the indigenous and tribal population, according to the 2011 Census, consists of $1,586,141$ people, or $1.8 \%$ of the total population of the country. The tribal students are very often deprived of adequate educational facilities. Their remote living areas, financial crises, and lack of familial or social supports can be considered the key issues for such deprivation. Despite being underprivileged and neglected in many aspects compared with the mainstream people, an extensive number of tribal students are emerging for higher studies (university/ tertiary level) at present. In the COVID-19 situation, whilst the whole world is working from home and the students, too, are learning from home, the virtual learning of the tribal students has become a matter of great concern. Moreover, it is necessary to ensure education for all of the post-pandemic worlds where online education might be more acceptable than on-sight education. So, this is high time for Bangladesh to make certain providing all technical supports with proper monitoring to all the under privileged students including the tribal students, because, without ensuring proper education for this vast population, it is not possible to make national prosperity. Education for all cannot be ensured without proper caring of the marginalized people in the society and in this pandemic situation it is essential to examine the proper implementation of online distance education everywhere. However, the paper aimed to investigate the practical scenario of virtual learning of tribal students in Bangladesh at the university level and goals to explore the challenges of it. Besides, the study recommended necessary measures. This study may be supportive of the concerned authority to take the necessary steps to build a bridge between mainstream students and tribal students regarding online education.

However, with realizing the necessity of virtual education, especially in the COVID-19 pandemic, some research works have been conducted worldwide on distance e-learning which is a combination of distance education and e-learning which is illustrated by the use of internet and web technology in the delivery of education and in such a way online communication makes the bridge between the temporal or spatial constraints [10]. However, the developing and underdeveloped countries cannot ensure such online education for all, more specifically, in many countries, minority groups and ethnic groups get deprived of such advanced facilities.

Some students prefer online learning because they do not need to rush to campus [11] with the advances of communication technologies [12] but the students of remote or hilly areas are not adequately privileged. So, geographical inclusion is needed where the students of all regions and all communities may receive equity in inclusive education regardless of the location of the community, but this has not been implemented always [13]. Dubey [14] found "discrimination based on caste, gender and culture" in his research on the tribal community and claimed not to get a significant result in the Digital Education (DE) classroom for the tribal students. He also stated the focus of the efforts in using technology in education "was more towards computer-aided learning than Distance e-Learning". In another study, Mullah, Parveen, and Ahshanullah [15] revealed that the tribal people were lagging behind the mainstream population particularly in the average cultivable land and the educational level of the population.

In another study, Sarker and Davey [16] mentioned that poverty is one of the main reasons that caused the drop out of ethnic minority children from education. According to their findings, too many tribal families engaging in income or family activities are the main concerns. Sharma [17] pointed out in his study that most of the tribal population lives in remote areas and are deprived of the privileges of "developmental reforms". They do not enjoy the facilities of the modern education system because of the "geographical isolation". Arya and Chauhan [18] found that tribal society was underprivileged and backward in education due to their less acquaintance with educational technology. The discrimination in education among the tribal groups is more vivid in Rezai Karim's statement. As an economics professor at Shahjalal University of Science and Technology, Bangladesh, he stated, "the rate of literacy in Bangladesh is far lower among the 
ethnic minorities than it is nationally" [5]. On the other hand, Asad [19] argued that quality teachers, quality content, and quality environment are the main deficiencies in the education sector of Bangladesh. According to him, creating a 'Knowledge-based Society' where the citizens are equipped with technical knowledge and skill is the major challenge for the country to develop in virtual education.

However, there was no similar study in the home or abroad on virtual learning of the Bangladeshi tribal students. Hence, the researchers intend to investigate the practical scenario of the online learning of the tribal students at the university level in this pandemic situation. The researchers believe that the present study will help to take steps for the better virtual learning of the tribal students in Bangladesh in the coming "new normal' days.

\section{RESEARCH METHOD}

The study followed a mixed-method approach [20] to be developed. So, different tools were used to conduct the study to find out the real scenario of the present condition of the subject matter. 73 tribal students from different universities in Bangladesh were purposefully selected of which 60 participants spontaneously responded in this online survey-based study. However, 60 participants were good enough as the indigenous people are only $1.18 \%$ of the country's total population [3]. However, Field [21] mentioned that a smaller (but hopefully representative) collection of units from a population is used to determine truths about that population.

An online questionnaire survey was conducted to collect the data and information from the contacted participants. A 'messenger group' was formed with all the participants. With their full consent, a structural questionnaire link using 'Google form' was sent to them through the messenger group. Among 73 students, 60 responded with complete information regarding the survey. The questionnaire was prepared with two general questions, five closed-ended questions (Yes/No/Sometimes), 10 questions using the Likert scale [22], and four questions to check multiple responses on their problems during online classes, frequently faced troubles regarding internet issue, the support they are getting presently and their expectations. All these tools were used for quantitative data analysis. For qualitative data analysis, Focus Group Discussion (FGD) was set up with few questions relevant to the query with 19 participants (at least one from each community), and Likert data to know better. Using FGD, the researchers got a vivid view of the socio-economic and educational structures of those communities. The data were administered to Microsoft Excel for figures and tables were inserted as required.

\section{RESULTS AND DISCUSSION}

\subsection{Demographic information of the participants}

Table 1 displays a vivid demographic of the participants. Of 60 students, $75 \%$ are males and $25 \%$ are females. The participants belong to different tribal groups in Bangladesh and the total community is 11 in number. Among them, 35\% of participants are from the Chakma tribe which is the largest tribal group of Bangladesh and the highest number on this list, followed by Marma (16.7\%), Garo (13.3\%), Santal (11.7\%), and Tripura (10\%). The rest participants of the list are from respectively Khumi, Khasiya, Tanchangya, and Hajong (1.7\% from each community).

Table 1. Participants' demographics

\begin{tabular}{lccc}
\hline & Participants $(\mathrm{n}=60)$ & Frequency $(\mathrm{n})$ & Percentage $(\%)$ \\
\hline Gender & Female & 15 & 25 \\
Communities $(\mathrm{n}=11)$ & Male & 45 & 75 \\
& Chakma & 21 & 35 \\
& Marma & 10 & 16.7 \\
& Garo & 8 & 13.3 \\
Santal & 7 & 11.7 \\
& Tripura & 6 & 10 \\
& Mro & 2 & 3.3 \\
Orao & 2 & 3.3 \\
& Khumi & 1 & 1.7 \\
& Khasiya & 1 & 1.7 \\
& Tanchangya & 1 & 1.7 \\
Hajong & 1 & 1.7 \\
\hline
\end{tabular}




\subsection{Participants' residences and institutions}

Table 2 shows the students' affiliation with their residence and institutions. It also depicts the movement of the students during the current public health emergency. The highest proportion of the students was from Khagrachari district (30\%), followed by Bandarban (20\%) and Rangamati (18.3\%). All these three districts are in the Chattagram division which is enriched with several tribal groups. Moreover, the highest concentration of students was found in the capital city Dhaka (55\%) as an institutional district, followed by Chattagram (10\%) and Noakhali (10\%). Dhaka and Chattagram are the two biggest cities in Bangladesh and are considered educational hubs in the country.

In response to the question of whether the participants live in remote areas from the main city in their respective districts, $75 \%$ answer in the affirmative, and $25 \%$ answer in the negative. In responding to the question of Quota, 68.3\% answer in the affirmative, and 31.7\% answer in the negative. Of 60 participants, 90\% of students have reported that they are residing in their places during COVID-19, and the rest $10 \%$ students have reported that they are staying at other places (relative's home, mess, or rented house) during the pandemic. Table 2 also shows the pattern of the respective universities of the participants. Among all the 22 universities $77.3 \%$ are public and the rest $22.7 \%$ are private universities. The survey shows that most of the students live in remote areas and they are deprived of the modern facilities of cities. Maximum students were found residing in their places during the pandemic. The study also depicted that the majority are from public university background as they get the quota facility at their study institutions.

Table 2. Information about participants' residences and institutions

\begin{tabular}{|c|c|c|c|c|c|c|c|}
\hline \multicolumn{4}{|c|}{ Home districts and living place during COVID-19 } & \multicolumn{4}{|c|}{ Institutions' location, types, students, and privileges } \\
\hline & & $\begin{array}{l}\text { Students } \\
\text { (n) }\end{array}$ & $\begin{array}{c}\text { Percentage } \\
(\%)\end{array}$ & & & $\begin{array}{l}\text { Students } \\
\text { (n) }\end{array}$ & $\begin{array}{c}\text { Percentage } \\
(\%)\end{array}$ \\
\hline Home & Bandarban & 12 & 20 & District of & Dhaka & 33 & 55 \\
\hline \multirow[t]{11}{*}{ districts } & Rangamati & 11 & 18.3 & institutions & Chattogram & 6 & 10 \\
\hline & Khagrachari & 18 & 30 & & Noakhali & 6 & 10 \\
\hline & Dinajpur & 5 & 8.3 & & Rajshahi & 3 & 5 \\
\hline & Joypurhat & 2 & 3.3 & & Gopalganj & 2 & 3.3 \\
\hline & Rangapur & 2 & 3.3 & & Sylhet & 2 & 3.3 \\
\hline & Netrokona & 3 & 5 & & Sirajganj & 2 & 3.3 \\
\hline & Mymensing & 3 & 5 & & Kushtia & 2 & 3.3 \\
\hline & Sherpur & 1 & 1.7 & & Dinajpur & 1 & 1.7 \\
\hline & Jamalpur & 1 & 1.7 & & Khulna & 1 & 1.7 \\
\hline & Tangail & 1 & 1.7 & & Cumilla & 1 & 1.7 \\
\hline & Moulvibazar & 1 & 1.7 & & Rangamati & 1 & 1.7 \\
\hline \multirow{4}{*}{$\begin{array}{l}\text { Living } \\
\text { places } \\
\text { Areas }\end{array}$} & Dhaka & 5 & 8.3 & Types $(n=22)$ & Public & 17 & 77.3 \\
\hline & Outside Dhaka & 55 & 91.7 & & Private & 5 & 22.7 \\
\hline & Main city & 15 & 25 & Students' quota & No & 19 & 31.7 \\
\hline & Remote areas & 45 & 75 & from the institution & Yes & 41 & 68.3 \\
\hline
\end{tabular}

\subsection{Information about online classes during COVID-19}

Table 3 shows the result of the close-ended questions. $63.3 \%$ of the participants joined virtual classroom or learning sessions from home so far. Notably, $81.7 \%$ of students want to join virtual learning platforms from their places. On the contrary, $31.7 \%$ use online video applications for different purposes at home. $66.7 \%$ of students face electricity problems in their respective areas. Only $21.7 \%$ of students informed that their family is capable to bear the expenses to operate online apps for classes. However, this survey shows that most of the participants have experienced virtual learning from home during the COVID-19 pandemic though they face discontinuation of electricity or financial crises.

Table 3. Students' insights about online classes

\begin{tabular}{lccc}
\hline \multicolumn{1}{c}{ Questions } & Yes & $\begin{array}{c}\text { No } \\
\text { Percentage }(\%)\end{array}$ \\
\hline Have you joined any virtual classroom/learning sessions from your home? & 63.3 & 13.3 & 23.3 \\
Do you want to join virtual learning platforms from your place? & 81.7 & 6.7 & 11.7 \\
Do you use online video applications for any purposes at home? & 31.7 & 41.7 & 26.7 \\
Do you face electricity problems in your home area? & 66.7 & 1.7 & 31.7 \\
Is your family capable to bear the expenses to operate online apps for classes? & 21.7 & 45 & 33.3 \\
\hline
\end{tabular}




\subsection{Results from the Likert-scale data}

The researchers set up 10 questions in the Five-point Likert-scale [22] to know the learners' sensitivities during COVID-19. Only the maximum percentages are analyzed and discussed below as the rest of the percentages are given in Table 4. The mean score of the participants' responses to the statement has been shown to specify the result of each statement of the questionnaire.

Table 4. Five-point Likert-scale for learner sensitivities during COVID-19

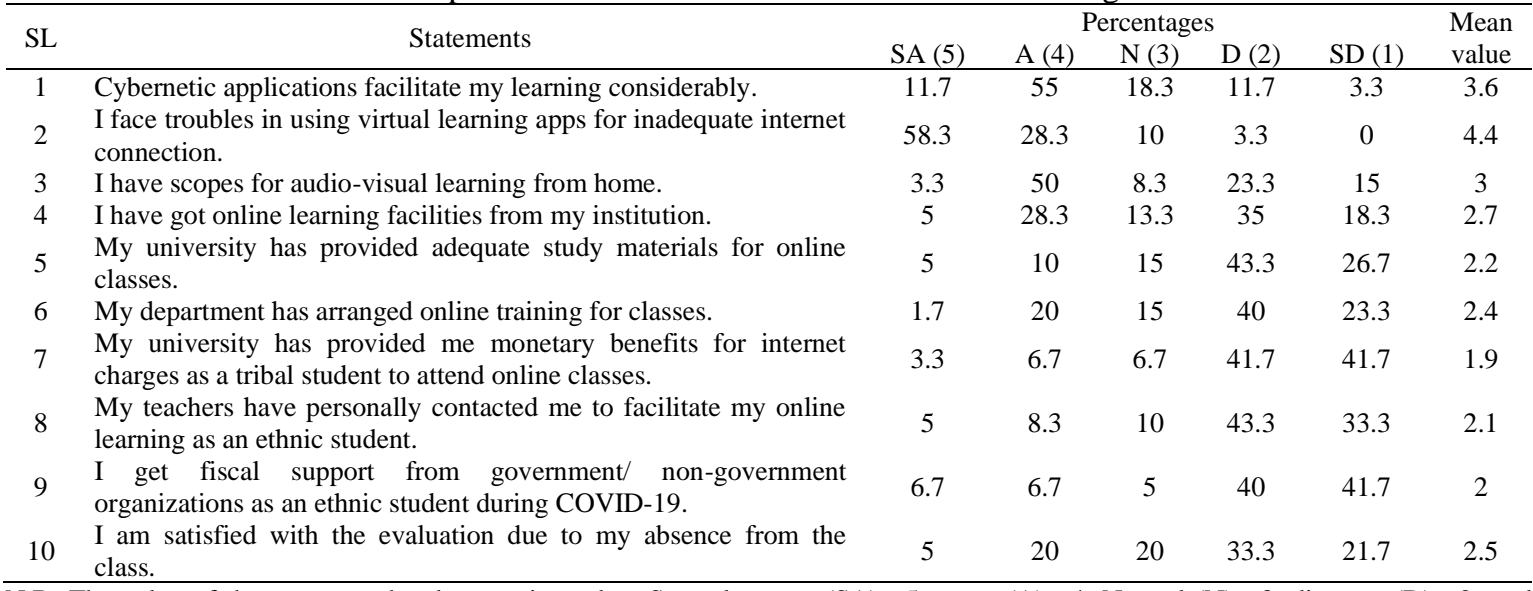

N.B. The value of the responses has been estimated as Strongly agree $(S A)=5$, agree $(A)=4$, Neutral $(N)=3$, disagree $(D)=2$, and strongly disagree $(\mathrm{SD})=1$.

In statement 1 , the students agree that they consider cybernetic applications for facilitating their learning (Mean 3.6). In statement 2, the students strongly agree that they face troubles in using virtual learning apps for inadequate internet connection (Mean 4.4). In responding to statement 3, the data (Mean 3) shows the neutral position of the students where it claims that the students have scopes for audio-visual learning from home. Statement 4 depicts that the students remain neutral about getting online learning facilities from their institutions (Mean 2.7). Then, the students were found neutral in statements 5 and 6 regarding the support of the universities to provide adequate study materials for online classes and the support of their department to facilitate their virtual learning for online classes (Mean 2.2 and 2.4 respectively). In statement 7 , the participants opined that they did not get any monetary benefits for internet charges as tribal students. In the last three queries even, the students appeared to be neutral regarding the teacher-student interaction during the pandemic, fiscal support from different organizations, and the evaluation process if the students cannot join the class.

\subsection{Multiple response analyses}

The researchers set four questions for multiple response analyses about online classes during the pandemic situation. The participants were asked about the key problems during online classes in the first question as shown in Figure 1. Responding to the first question, $70 \%$ of the students marked anxiety of the assessment process as the problem while $68.3 \%$ of students face familial troubles. In connection with the familial circumstances, Selim [23] also pointed out the parent's financial insolvency causes trouble for learning. However, the home condition sometimes may not be favorable for joining an online class even. Notably, 23.3\% opined about English language problems.

Figure 2 shows the responses to the second query. Students were asked about the internet-related frequently faced troubles for joining an online class, $86.7 \%$ of the participants mention about internet charge and $65 \%$ of the students answer that they do not get adequate internet connection while $45 \%$ of students face internet buffering issue also. 


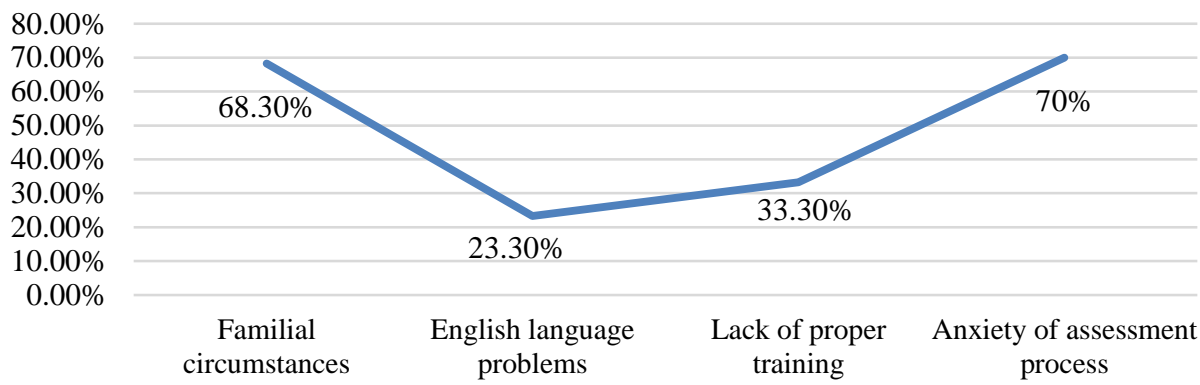

Figure 1. Problems faced by the students during online classes

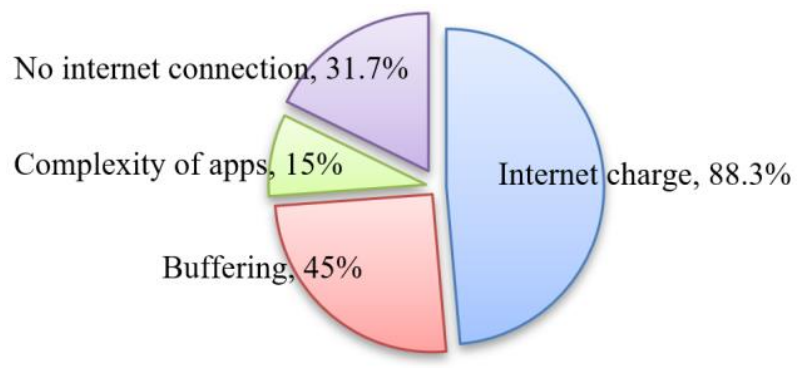

Figure 2. Frequently faced troubles for online classes

Responding to the third question where the question was set to know about the facilities that the tribal students get from the quota system during the COVID-19 pandemic. There are $78.3 \%$ of the students opined that they do not get any facility only a handful of the participants got benefits from the quota system which is the usual system of their university.

However, Table 5 reveals the responses of the fourth question. The table shows that $76.7 \%$ of participants expect government support to attend virtual learning platforms while $75 \%$ want support for internet connection and $66.7 \%$ wish for their respective university's support. Rest $13.3 \%$ of the participants expected their family support.

Table 5. The facilities students enjoying currently and the supports they expect

\begin{tabular}{lclc}
\hline \multicolumn{1}{c}{ Quota facilities enjoying by the participants } & Responses & Supports expected & Responses \\
\hline Financial benefits & $5 \%$ & Government support & $76.7 \%$ \\
Logistic support & $10 \%$ & University support & $66.7 \%$ \\
Technological facility & $6.7 \%$ & Internet connection & $75 \%$ \\
No facility & $78.3 \%$ & Family support & $13.3 \%$ \\
\hline
\end{tabular}

\subsection{Synopsis of focus group discussion (FGD)}

An online FGD was arranged through the zoom platform to directly know the participants' wants, remarks, and needs for virtual learning. At least one from each tribe was recommended to join the FGD along with others, though, only 19 participants joined the discussion session. The researchers came to know that private universities started classes earlier than public ones. However, FGD revealed the students' expectations in the new normal period that most of them want to continue attending online classes as a part of the regular classes during ones' absence due to familial or physiological circumstances. Some participants think that universities should have the management to allow students online if anyone is at home. However, higher education institutions should also consider students' satisfaction in determining the quality of their online learning [24].

Some students expect the existing quota system for the minorities and the tribal students should have more financial assistance to bear the expenses for their virtual learning. Besides, the universities, particularly, the departments should initiate increasing their internal facilities, especially for the tribal students. The university authority should take extra care of the tribal students regarding their attendance, performance, and assessment of the online classes due to their absences in the classes. A participant

Virtual learning of the tribal students in Bangladesh: Constrictions and ... (Quazi Farzana Yesmin) 
mentioned that the departments of all universities need to open a committee as the students can report their inconveniences regarding their online education during the COVID-19 situation. Another participant added that training sessions are repeatedly required for the students about using new apps or systems for online class or assessment as the students can overcome fear and attend the sessions. The participants also expected a quota system for the tribal students in private universities as well, because most of the private universities do not have sufficient quota facilities for the minority groups.

\subsection{Recommendations for policy and practice}

The National Education Policy [25] aimed at fetching indispensable modifications in the "pedagogy, and teachers' capacity building" where Information Communication Technology (ICT) is considered as an effective tool [26]. But the implementation has not been satisfactory especially in the remote or hilly areas where the tribal participants live. Moreover, a recent study, conducted by Advocacy for Social Change (ASC) [27] has reported that education officials are not adequately monitoring the progress of online learning in Bangladesh during the pandemic. They have also marked the limitations of the teachers for ineffective online learning programs in Bangladesh. But regular monitoring and teachers' understanding is important for effective distance learning. As teaching and learning are complex exercises that require teachers to fully understand the effects of context and learner variability [28], [29]. McDonald and Tufue-Dolgay [30] considered that the teachers of such remote areas should be provided with more training for professional growth to implement inclusive practices and develop resources that are ethnically pertinent for learning efficacy. However, the government should pay extra attention to the advancement of the tribal students' virtual study during the pandemic. As the entire world is going to experience a new normal life, every sector of the Ministry of Education or the Education Board should be equally concerned about the tribal students like the mainstream students and should take proper steps for their betterment.

However, along with others, students are facing challenges because of inappropriate learning attitudes, insufficient materials for learning, involvement in the classes, and the inadequate home environment as well as for having little capability over self-discipline during this pandemic [31], [32]. Therefore, the study hereby suggests six key points as recommendations to improve the present virtual condition of tribal education. The first one is the concept of 'flipped classroom' and 'blended learning'. To create a situation with blended learning, the government and the University Grants Commission (UGC) should design and deploy a post method pedagogic approach to develop online learning environment. Online education has already been persuasively implemented globally [33], so, it is high time the authority should introduce flipped classroom to boost the traditional approaches of education for tribal pupils. Secondly about 'assessment anxiety', as many students did not find online assessment comfortable, the authority must monitor if the online assessment is flexible and student-friendly so that students can perform in the online classes and exams with relaxation and confidence. Thirdly comes the point of 'logistic support'. Students may be provided with the logistic amenities (e.g., financial aid) as per their familial or socio-economic condition. Regarding that, the equity should be maintained rather than equality. Fourthly, the issues of 'internet connection' and 'internet charge' appear.

As it is also a stately matter, the government and the respective directorate along with the mobile operator companies should take effective measures to develop a satisfactory level of internet connection and a reasonable charge to facilitate the teaching-learning process as well as to contribute to the development of the country. 'Intervallic electricity supply' is the fifth point that the research depicts. To make easy internet access, the continuance of the electricity supply is a must. Hence, the respective authority should make sure of the continuity of electricity supply in the remote areas, especially in the hilly tracts. In this regard, necessary measures should be taken within a short period. Last but not least is the 'quota facilities' for being the tribal students. The university authority, the ministry of education, and UGC should prepare a year-wise plan for the tribal students to ensure adequate facilities from the quota system. So, the quota system should be revised also.

\section{CONCLUSION}

It is mentionable that public universities started online classes later than private universities. So, the study may not be generalized for all students, nevertheless, the results showed a real scenario of the tribal students' virtual learning constrictions. Besides, this study was inspired by observing the situations during the COVID-19 pandemic, but the impact was analyzed for an overall condition of the tribal students' virtual learning. Education is among the primary concerns of all societies and tribes. New methods and technological aids can enhance educational efficacy credibly. Although online education has become more popular in the pandemic time, it can be an alternative means of traditional education as well. The emergency of adopting with the virtual world has arisen for the 'new normal' life as the scientists and the experts are 
alerting the world about the long term or lifetime existence of COVID-19 in the world. Hence, this is high time to prepare the students to cope with the new education system and every possible measure should be taken for online classes instead of on-campus classes.

Ensuring education for all, it is also essential to pay equal attention to the tribal students in our country as the ethnic groups are underprivileged and deprived in many aspects of society. If we cannot ensure a better education life for the tribal students now, it will not be possible to ensure a better future for them. As the tribal students can advance in the new normal life, the authority should ensure a web-based learning platform for smooth virtual learning to continue their higher education from their living place. Therefore, further research scopes e.g., strategies and applications of blended learning, new and flexible methods for the new normal period are still to be explored.

\section{ACKNOWLEDGEMENTS}

The researchers are thankful to 'Hello-Teen Society' (Govt. Registration No. S-13170), an organization for education, research, and welfare in Bangladesh for the overall support in terms of doing the study, but the organization did not play any direct role to conduct the study.

\section{REFERENCES}

[1] United Nations Development Program (UNDP), 10 things to know about indigenous peoples. [Online]. Available: https://stories.undp.org/10-things-we-all-should-know-about-indigenous-people. (accessed Jan. 25, 2019)

[2] A. Khan, "Education for indigenous children," The Daily Star, 2014. [Online]. Available: https://www.thedailystar.net/education-for-indigenous-children-35129.

[3] IWGIA, Indigenous Peoples in Bangladesh, The Indigenous World 2021: Bangladesh. Mar. 2021. [Online]. Available: https://www.iwgia.org/en/bangladesh/4201-iw-2021-bangladesh.html.

[4] N. Khattab, "Ethnicity and higher education: The role of aspirations, expectations and beliefs," Ethnicities, vol. 18, no. 4, pp. 457-470, 2018, doi: 10.1177/1468796818777545.

[5] Relief Web, Ethnic minorities face higher school drop-out risk, 2011. [Online]. Available: https://reliefweb.int/report/bangladesh/ethnic-minorities-face-higher-school-drop-out-risk.

[6] P. Blessinger and J. P. Anchan, Democratizing higher education: International comparative perspectives. New York, Routledge, 2015.

[7] J. Seale, J. Georgeson, C. Mamas, and J. Swain, "Not the right kind of 'digital capital'? An examination of the complex relationship between disabled students, their technologies, and higher education institutions," Computers \& Education, vol. 82, pp. 118-128, 2015, doi: 10.1016/j.compedu.2014.11.007.

[8] D. M. Hossain, "Socio-Economic Situation of the Indigenous People in the Chittagong Hill Tracts (CHT) of Bangladesh," Middle East Journal of Business, vol. 8, no. 2, pp. 22-30, 2013, doi: 10.5742/MEJN. 2013.82231.

[9] International Labour Organization (ILO), Building capacities on indigenous and tribal peoples' issues in Bangladesh. Apr. 2017. [Online]. Available: https://www.ilo.org/wcmsp5/groups/public/---asia/---ro-bangkok/--ilo-dhaka/documents/publication/wcms_563690.pdf.

[10] R. Garrison, E-Learning in the 21st century: A framework for research and practice, 3rd ed. London: Routledge/Taylor and Francis, 2017.

[11] K. C. Green, The 2010 Campus Computing Survey. Encino, CA: The Campus Computing Project, 2010. [Online]. Available: http://www.campuscomputing.net/2010-campus-computing-survey.

[12] B. Kan Kilınc, B. Yazıc1, B. Gunsoy, and G. Gunsoy, "Perceptions and Opinions of Graduates about the Effects of Open and Distance Learning in Turkey," Turkish Online Journal of Distance Education, vol. 21, no. 1, pp. 121-132, 2020, doi: 10.17718/tojde.690369.

[13] H. A. Begum, R. Perveen, E. Chakma, L. Dewan, R. S. Afroze, and D. Tangen, "The challenges of geographical inclusive education in rural Bangladesh," International Journal of Inclusive Education, vol. 23, no. 1, pp. 01-16, 2018, doi: 10.1080/13603116.2018.1514729.

[14] N. Dubey, "Conversion of education system to tribal community by digital education," The Research Journal of Social Sciences, vol. 10, no. 7, pp. 45-55, 2019.

[15] M. A. S. Mullah, N. Parveen, and M. Ahshanullah, "Tribal People and their Socio-Economic Characteristics in Rangamati Sadar Thana," BRAC University Journal, vol. 4, no. 1, pp. 47-58, 2007.

[16] P. Sarker and G. Davey, "Exclusion of indigenous children from primary education in the Rajshahi Division of northwestern Bangladesh," International Journal of Inclusive Education, vol. 13, no. 1, pp. 01-11, 2009, doi: $10.1080 / 13603110701201775$

[17] R. K. Sharma, "Problems of professional education in tribal areas of India," International Journal of Research in Finance and Management, vol. 1, no. 1, pp. 24-29, 2018.

[18] S. Arya and T. Chauhan, "A Critical Study of Tribal Education: With Special Reference to Women's," Conference: International Seminar on Tribal Development, Pacific University, Udaipur, Rajasthan, vol. 1, 2012. [Online]. Available: https://www.researchgate.net/publication/276174073.

[19] A. Asad, "E-learning in Bangladesh: A New Era in the Field of Education," Bangladesh Education Article, 2009. [Online]. Available: https://bdeduarticle.com/e-learning-in-bangladesh-a-new-era-in-the-field-of-education.

[20] B. K. Lynch, Language program evaluation: Theory and practice. Cambridge: Cambridge University Press, 1996. 
[21] A. Field, Discovering Statistics Using SPSS, 2nd ed. Sage Publications, London. 2005.

[22] R. Likert, "A technique for the measurement of attitudes," Archives of Psychology, vol. 22, no. 140, pp. 1-55, 1932.

[23] S. Selim, "Language Problem in Educating Indigenous Children of Chittagong Hill Tracts in Bangladesh," International Journal of Humanities Social Sciences and Education (IJHSSE), vol. 4, no. 6, pp. 31-36, 2017, doi: 10.20431/2349-0381.0406004.

[24] F. Bayrak, M. H. Tibi, and A. Altun, "Development of Online Course Satisfaction Scale," Turkish Online Journal of Distance Education, vol. 21, no. 4, pp. 110-123, 2020.

[25] The National Education Policy-2010, Ministry of Education, Government of the People's Republic of Bangladesh.

[26] K. M. A. Islam and M. S. S. Bhuiyan, "Growing Importance of ICT in ELT for Effective Pedagogy during COVID19 Pandemic in Bangladesh," Journal of ELT and Education, vol. 3, no. 3, pp. 106-115, 2020.

[27] BRAC, "Impact of COVID-19 on Education in Bangladesh," Advocacy for Social Change (ASC), BRAC, in collaboration with BEP, May 2020. [Online]. Available: http://www.brac.net/program/wpcontent/uploads/2020/07/Rapid-assessment-impact-of-COVID-19-education-in-Bangladesh.pdf.

[28] L. Darling-Hammond and J. Snyder, "Authentic Assessment of Teaching in Context," Teaching and Teacher Education, vol. 16, no. 5/6, pp. 523-545, 2000.

[29] M. J. Taole, "Diversity and inclusion in rural South African multigrade classrooms," International Journal of Inclusive Education, vol. 24, no. 12, pp. 1268-1284, 2018, doi: 10.1080/13603116.2018.1520310

[30] L. McDonald and R. Tufue-Dolgoy, "Moving Forwards, Sideways or Backwards? Inclusive Education in Samoa," International Journal of Disability, Development and Education, vol. 60, no. 3, pp. 270-284, 2013, doi: 10.1080/1034912X.2013.812187.

[31] K. Brazendale, et al., "Understanding differences between summer vs. school obesogenic behaviors of children: the structured days hypothesis," International Journal of Behavioral Nutrition and Physical Activity, vol. 14, no. 1, 2017, doi: 10.1186/s12966-017-0555-2.

[32] V. D. Soni, "Global Impact of E-learning during COVID 19," SSRN Electronic Journal, 2020, doi: 10.2139/ssrn.3630073.

[33] P. Paudel, "Online Education: Benefits, Challenges and Strategies During and After COVID-19 in Higher Education," International Journal on Studies in Education (IJonSE), vol. 3, no. 2, pp. 70-85, 2021, doi: 10.46328/ijonse.32. 